\title{
Alternaria alternata - the main causal agent of disease symptoms in juniper, rose, yew and highbush blueberry in nurseries in southern Poland
}

\author{
Malgorzata Nadziakiewicz, Halina Kurzawińska, \\ Stanisław Mazur*, Dorota Tekielska \\ Department of Plant Protecion \\ Faculty of Biotechnology and Horticulture \\ University of Agriculture in Krakow \\ 29 Listopada 54, 31-425 Kraków, Poland
}

\begin{abstract}
Symptoms of discoloration and necrosis of the leaves/needles and shoots of plants are an increasingly common phenomenon in nurseries. They necessitate the withdrawal of the affected plants from sale, which has significant economic consequences. In 2010-2011, observations were conducted of the health of shrubs in nurseries of the Małopolska province. Disease symptoms were mostly found in juniper (Juniperus horizontalis 'Wiltonii'), rose (ground-cover rose 'Star Profusion'), yew (Taxus $\times$ media 'Hillii') and highbush blueberry (Vaccinium corymbosum 'Patriot'). These species were selected for further study. The affected shrubs represented more than $46 \%$ of the population of a given species. Fragments of the diseased organs: the leaves or needles, the base of the shoots, and the roots, were collected from the borderline between healthy and diseased tissue, and used to isolate and identify the microorganisms colonizing the diseased parts. The affected organs were found to be inhabited to the largest extent by the fungus Alternaria alternata (Fr.) Keissl., which accounted for 19.7 to $47.5 \%$ of the isolates from the tested species of shrubs. There were also large populations of fungi of the genera: Botrytis (up to $9.82 \%$ ), Cladosporium (up to 5.66\%), Colletotrichum (up to 5.13\%), Fusarium (up to 18.38\%), Mortierella (up to 7.26\%), Pestalotia (up to 5.36\%), Rhizoctonia (up to 5.36\%), Sclerotinia (up to 6.99\%), and Trichoderma (up to $17.09 \%$ ). The fungus $A$. alternata, being by far the dominant pathogen, was tested for its pathogenicity for the shoots of the chosen species of shrubs. The test was conducted for 14 days in a chamber with parameters so programmed that they reflected the natural conditions at the height of the growing season. The fungus A. alternata exhibited pathogenicity for all of the tested species of shrubs. Necrosis developed on all the inoculated fragments of shoots. The surface area of necrotic lesions was larger on the shoots of juniper and blueberry.
\end{abstract}

Keywords: Alternaria alternata, DNA, pathogenicity

\section{INTRODUCTION}

The nature of plant production is such that it is not possible to separate it from the influence of external factors. Among biotic factors, phytopathogenic fungi are a major infectious agent in plants, as more than $70 \%$ of major diseases of crops are caused by fungi (Agrios, 2005; Larraňagal et al., 2012)

Fungi of the genus Alternaria are ubiquitous, occurring in large numbers in the organic matter

*Corresponding author. 
in the soil (Lou et al., 2013). Many species are saprotrophs, plant pathogens or crop pathogens. Pathogenic Alternaria fungi cause diseases of various crop plants and are present on all continents (Chase, 2005; Perello and Sisterna, 2006). They also infect ornamental plants and fruit trees and shrubs (Windham, 2008; Kakalikova et al., 2009; Pegg et al., 2014, Andersen et al., 2015).

Alternaria fungi, due to their prevalence and genetic variation, constitute a major threat in the cultivation of plants (Kakvan et al., 2012). Already in 1960, Pomerlau and Nadeau named the fungi of Alternaria spp. as the cause of withering of $20-65 \%$ of seedlings of coniferous plants in nurseries. Likewise, James and Woo (1987) found that seedlings of conifers infected by Alternaria alternata withered away completely.

Sharma et al. (2013) found that analyses performed on genomic DNA from A. alternata isolates derived from various host plants showed a high level of genetic variation. When planting ornamental plants, our primary goal is the decorative effect, and in the case of fruiting plants it is their ability to produce a valuable crop, so the choice of appropriate species and varieties of plants introduced into our garden is as important as their health. The quality of plant material produced by nurseries is therefore a factor that largely influences subsequent vegetative growth of all the plantings. For several years, nursery producers have been reporting disease symptoms appearing on the aboveground parts of some species of shrubs. Initially, it is a change in colour of the shoot tips and development of lesions on the leaves of deciduous plants, followed by withering of the affected organs. This phenomenon is more and more common and necessitates the withdrawal of large numbers of plants from sale, which makes it increasingly important economically. In this situation, it has become necessary to determine the causes of the observed symptoms. The objects of the study were plants of the species in which disease symptoms in nurseries had been observed most frequently: juniper, rose, yew, and highbush blueberry.

The aim of the study was to investigate the effect of mycorrhizal inocula on the growth, development and health of these plant species.

\section{MATERIAL AND METHODS}

In 2010-2011, disease symptoms on the leaves/ needles and the shoot base of plants in nurseries of the Małopolska province were most often found in creeping juniper, rose, yew and highbush blueberry. This was the basis for the selection of shrubs of these species for thorough examination and analysis. Five nurseries, where all of these shrubs were grown, were selected. In 2010 and 2011, from April to October, monthly observations of the health condition of three-year-old plants of the chosen species were conducted. In 2011, plants with disease symptoms: discoloration, necrotic lesions, withering of the leaf blade/needles and shoots, were collected from the nurseries. Five plants of each species were selected for the study. From each plant, six leaves or needles, depending on the plant, were taken. In the laboratory, all of the samples were initially rinsed with water. Then, using a sterile scalpel, four small fragments were taken from the borderline between necrotic lesions and healthy tissue; these were cut into $0.5-1.0 \mathrm{~cm}$ pieces and subjected to surface disinfection. The disinfected plant material was thoroughly dried with sterile absorbent paper and laid out, four pieces at a time, on a glucose-potato medium and a pea medium in Petri dishes. After a period of incubation in a thermostat at a temperature of $22-23^{\circ} \mathrm{C}$ for four to seven days, successively appearing colonies of fungi were split off and inoculated onto PDA slants. After homosporous cultures had been obtained, they were transferred onto suitably selected media and identified to the level of species. In addition to the PDA medium, rice and potato media were also used to identify fungi of the genus Fusarium. The isolated fungi were identified using mycological keys (Riffai, 1969; Ellis and Ellis, 1988; Kwaśna et al., 1991; Dugan, 2006; Domsh et al., 2007; Klaus et al., 2008). The frequency of occurrence of the different species of fungi was determined on the basis of the number of the obtained isolates of a given fungus, which was expressed as a percentage.

Pathogenicity of the isolates for the shoots of plants was tested with five isolates of A. alternata originating from the shrubs under study. The experiment was set up in five replicates, each with 5 fragments of shoots $(8 \mathrm{~cm}$ long) for each plant species. Five-millimeter diameter discs were cut out with a cork borer from 14-day-old mycelium of A. alternata. Transparent plastic boxes were bottomlined with a double layer of filter paper, and $20 \mathrm{ml}$ of sterile distilled water was poured onto it. Next, five plant fragments were placed inside each of these boxes; the fragments were pricked with a sterile needle and the prick spots were covered with the discs overgrown with the mycelium of A. alternata; the inoculation was with the isolate derived from 
the same plant species. The control consisted of the shoots of the same species of plants, inoculated with discs of the glucose-potato medium only.

The boxes with the fragments of plants were snap-closed and transferred to a Sanyo Versatile Environmental Test Chamber MLR-351H. The parameters programmed in the chamber were chosen to reflect the natural conditions at the height of the growing season (Tab. 1). The test in the chamber was conducted for 14 days. While in progress, the conditions of the test were checked regularly. The discolorations that appeared were measured: the length and width of the necrotic lesions on the shoots. After the completion of the experiment, reisolation of the fungi from the shoots was performed to confirm the presence of the infectious agent in plant tissue. The obtained results were subjected to statistical calculations (computer program Statistica 12) by ANOVA variance analysis. The validity of the differences between the combinations was checked by the Tukey test, with a significance level of $p=0.05$.

The $A$. alternata isolates obtained from the diseased parts of the tested species of shrubs were subjected to molecular analysis. For this purpose, DNA was isolated from 14-day-old cultures of A. alternata grown on the potato-glucose medium. The mycelium of each isolate separately was collected from the Petri dish and homogenized by grinding in a ceramic mortar in liquid nitrogen. DNA was then isolated using the Invisorb Spin Plant Mini Kit (Symbios). RAPD-PCR amplification was performed using DNA of four A. alternata isolates with OPAD12 primer (AAGAGGGCGT). RAPDPCR mixture was prepared according to Table 2. The dye used was ethidium bromide. The products of RAPD-PCR amplification were separated by $1.5 \%$ agarose gel electrophoresis in $1 \times$ TBE buffer at a voltage of $80 \mathrm{~V}$ for 1.5 hours. Visualization of the results was carried out by irradiating the agarose gel with UV light in a Gel Doc EZ Imager (Bio-Rad).

Table 1. Parameters in the pathogenicity test of Alternaria alternata

\begin{tabular}{lllccc}
\hline Hours & & Temperature $\left({ }^{\circ} \mathrm{C}\right)$ & Degree of exposure & \multicolumn{2}{c}{ Relative humidity } \\
RH $(\%)$
\end{tabular}

Table 2. Composition of RAPD-PCR mixture with the DNA of Alternaria alternata isolates and OPAD12 primer

\begin{tabular}{lcc}
\hline Reagents & $\begin{array}{c}\text { Concentration in the reaction } \\
\text { mixture }\end{array}$ & $\begin{array}{c}\text { Content in the reaction mixture for } \\
1 \text { sample }(\mu \mathrm{l})\end{array}$ \\
\hline Taq buffer [750 mM Tris-HCl; $\mathrm{pH} 8.8 ; 200 \mathrm{mM}$ & $1 \times$ & 2.0 \\
$\left(\mathrm{NH}_{4}\right)_{2} \mathrm{SO}_{4} ; 0.1 \%$ Tween20]* & $1.5 \mathrm{mM}$ & 1.2 \\
$\mathrm{MgCl}_{2} 25 \mathrm{mM}^{*}$ & $0.1 \mathrm{mM}$ & 0.8 \\
$\mathrm{dNTP}^{2} .5 \mathrm{mM}^{*}$ & $0.5 \mathrm{U}$ & 0.4 \\
Taq polymerase* & $0.2 \mathrm{mM}$ & 0.4 \\
Primer & - & 13.2 \\
Distilled water & $20 \mathrm{ng} \mu \mathrm{l}^{-1}$ & 2.0 \\
DNA & - & 20.0 \\
Total & & 2 \\
\hline
\end{tabular}

*Thermo Scientific 


\section{RESULTS AND DISCUSSION}

Symptoms of discoloration and withering of the leaves/needles and shoots, and sometimes of entire plants, occurred on all of the examined shrubs in all of the nurseries selected for the study. In both years of observations of the health of shrubs of the selected species, the percentage of infected plants was high, reaching values of more than $46.0 \%$ in all of the nurseries. Information on the pathogenic effect of Alternaria alternata on ornamental plants can also be found in the literature. According to Atilano (1983), the lesions caused by Alternaria spp. on the leaves are endemic to many species of plants grown in nurseries.

In the creeping juniper variety Wiltonii there appeared initially light green sections of withering shoots. Later, their colour changed to light brown. The number of shoots infected in this way increased with time. The lesions on the leaves of the rose variety Star Profusion were unevenly distributed on the surface of the leaf blade; they were light brown in colour, and their shape was irregular. The needles of yew shrubs of the variety Hillii changed their colour initially to light celadon, then to yellow, and in the final stage to light brown. With time, the plants withered away. The tips of the shoots of the northern blueberry variety Patriot initially became claret-coloured, but remained alive. Towards the end of the growing season they withered only as far as the boundary of discoloration, and then crumbled away. The remaining part of the plant resumed vegetative growth in the spring, but the new growth was shorter, and the branching not as extensive.

As a result of the mycological analysis of the leaves and needles of the test plants collected in 2011 and 2012, a total of 592 fungal isolates and 18 bacterial isolates were obtained (Tab. 3). On the basis of the frequency of occurrence, A. alternata was among the dominant fungi isolated from the leaves/needles of the diseased shrubs. This fungus was isolated in the largest numbers from the needles of juniper $-72.22 \%$, in considerably smaller numbers from yew needles $-42.11 \%$, and in the lowest percentages from the leaves of blueberry $-25.32 \%$ and rose $-23.08 \%$ (Tab. 3). Fungi of the genus Fusarium were also isolated in considerable amounts: $24.59 \%$ from yew needles, $17.72 \%$ from blueberry leaves, $17.31 \%$ from rose leaves, $9.26 \%$ from juniper needles (Tab. 3). Colonies of Botrytis cinerea were isolated in smaller numbers: $17.31 \%$ from rose leaves; $8.77 \%$ from yew needles; $5.56 \%$ from juniper needles; $3.80 \%$ from blueberry leaves (Tab. 3).
In the creeping juniper shrubs of the variety Wiltonii, the bark of the shoot base was very dark. The base of the stems in the rose variety Star Profusion was heavily discoloured to a dark, brown and purple colour. These changes extended high above the ground surface. The shoot base in the yew variety Hillii was dark brown, almost black. The lowest part of the base of shoots of the 'Patriot' northern highbush blueberry was discoloured to an intense brown.

As a result of the mycological analysis of the diseased base of the shoots of the test plants collected in 2011-2012, a total of 604 fungal isolates and 20 bacterial isolates were obtained. Among all the isolates, except for blueberry, the most dominant was the fungus Alternaria alternata. The largest numbers of it inhabited the diseased base of rose stems $-56.92 \%$ (Tab. 4). Slightly fewer isolates of A. alternata were isolated from the diseased base of yew shoots $-42.86 \%$, and the fewest from the diseased base of the shoots of juniper $-35.14 \%$ (Tab. 4).

Fungi of the genus Fusarium also had a large share in the total number of the isolates obtained: $26.39 \%$ from the diseased base of blueberry, $18.46 \%$ from the diseased base of rose, $17.57 \%$ from the diseased base of juniper, and the smallest number $-9.89 \%$ from the diseased base of yew (Tab. 4). Botrytis cinerea was also isolated in considerable amounts: $13.51 \%$ from the diseased base of juniper and slightly less $-9.89 \%$ from the diseased base of yew (Tab. 4). The most numerous fungus isolated from the diseased base of blueberry was Sclerotinia sclerotiorum - $19.44 \%$ (Tab. 4). Among the dominant fungi colonizing the diseased base of the shoots of the test shrubs were fungi of the genus Trichoderma - from $23.61 \%$ in blueberry to $6.15 \%$ in rose (Tab. 4). The dominant fungi colonizing the diseased base of yew shoots were the fungi Pestalotia sydowiana - $13.19 \%$, and Chaetomium globosum - 9.89\% (Tab. 4). The dominant, potentially pathogenic, fungus colonizing the diseased base of rose shoots was Verticillium albo-atrum $-6.15 \%$ (Tab. 4).

The root system of the tested shrubs exhibited symptoms of disease. After removing the creeping juniper variety Wiltonii from the pot, it was found that the roots were well-developed, with many lateral branches, but some of them had turned brown. The roots of the rose variety Star Profusion were poorly branched, with clearly visible dark brown sections. The root system of the yew cultivar Hillii was brown, poorly developed, with 


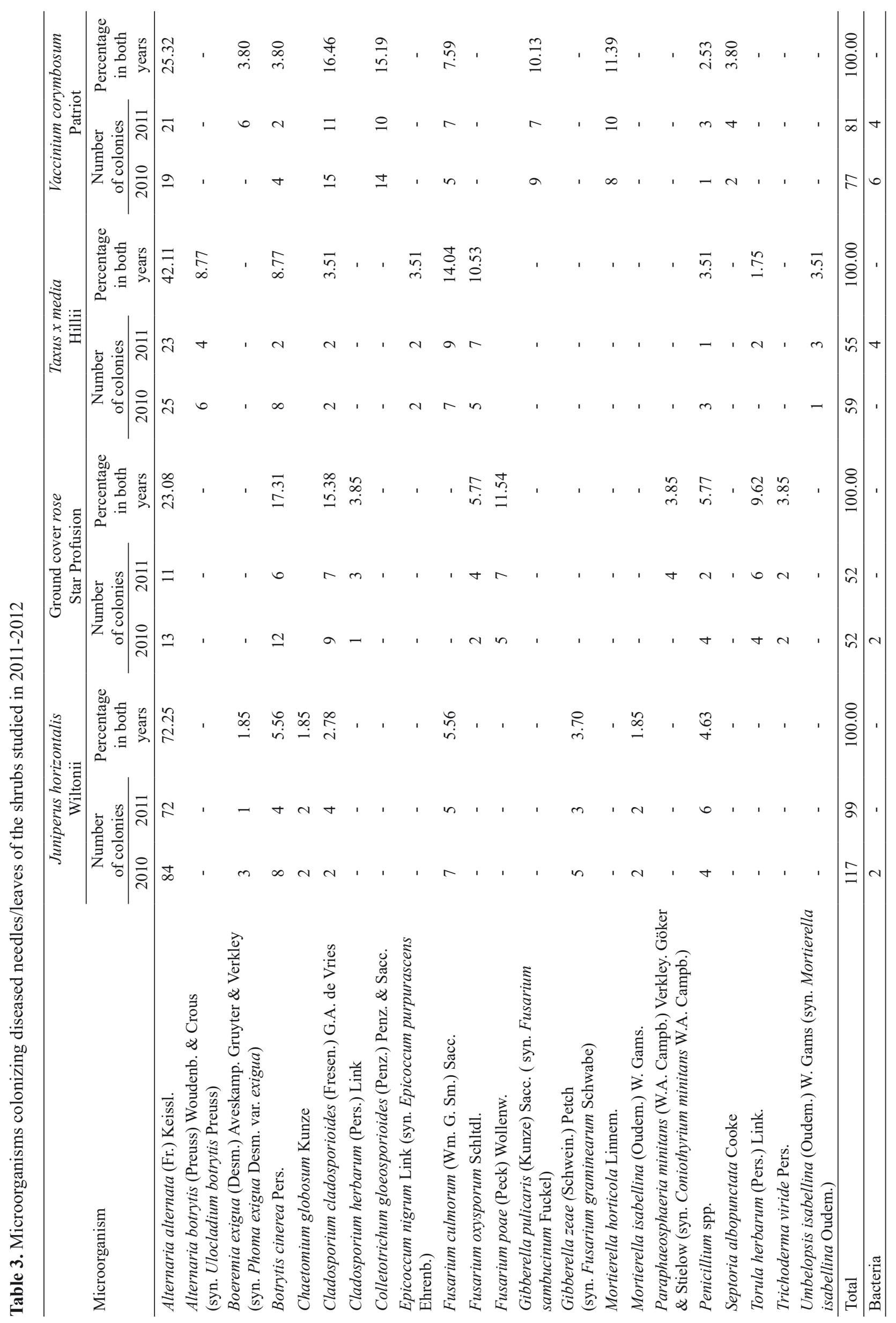




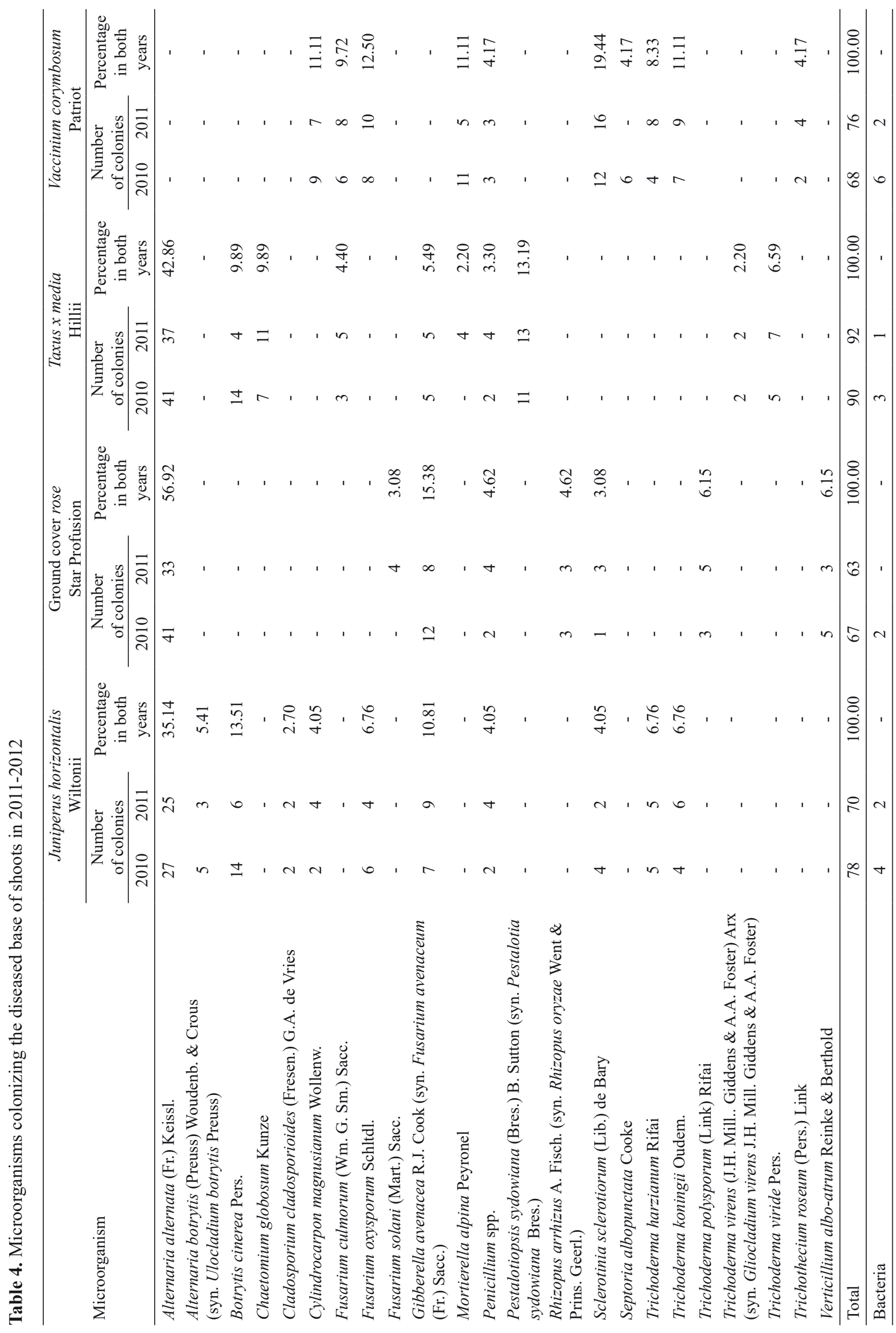




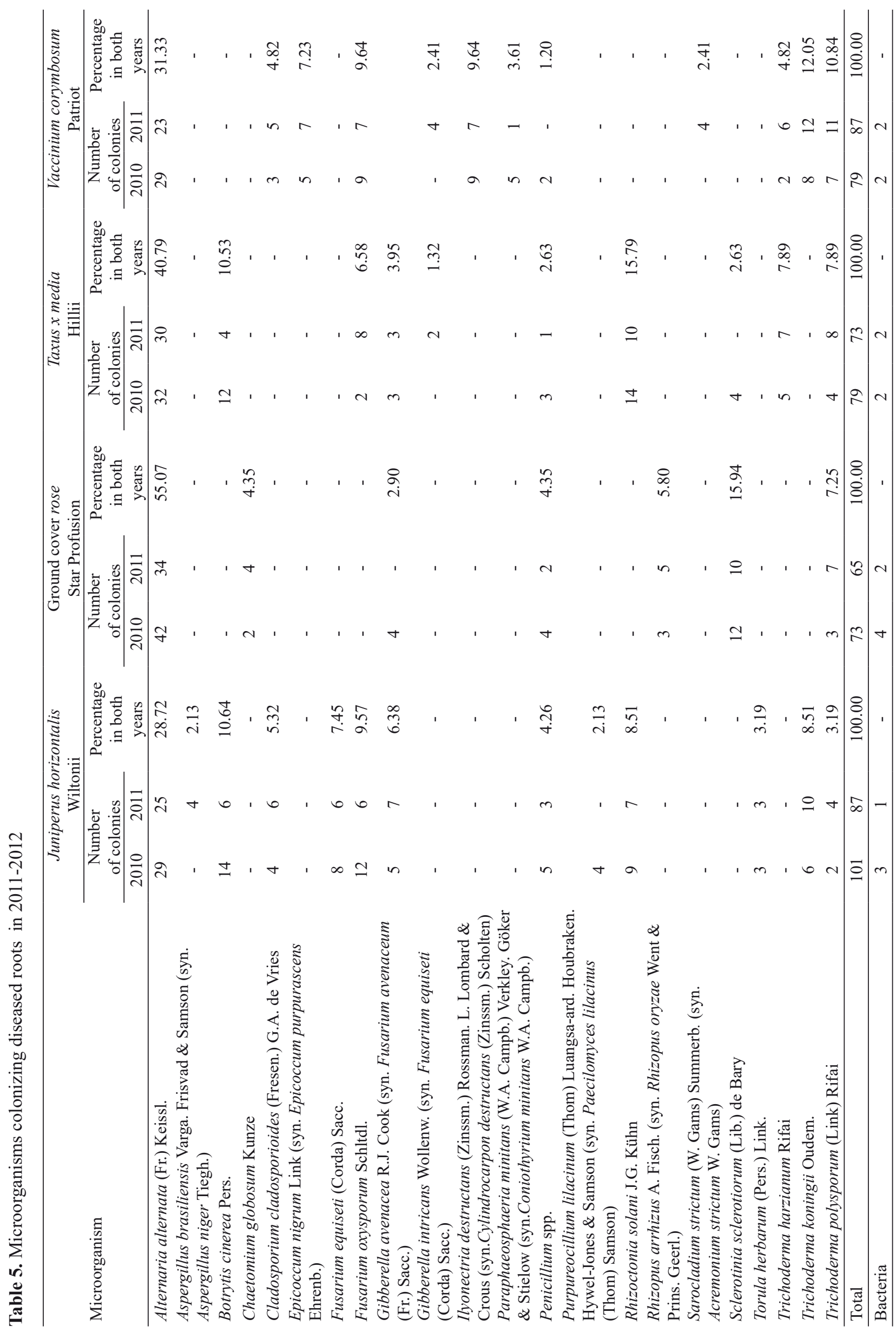


short intertwined roots without new growth. After removing the northern highbush blueberry 'Patriot' from the container, the roots were found to be welldeveloped, with numerous branches, and small dark brown sections.

As a result of the mycological analysis of the root system of the test plants collected in 2011-2012, a total of 644 fungal isolates and 18 bacterial isolates were obtained. Among all the isolates, Alternaria alternata was by far the most dominant fungus. It inhabited in the largest numbers the roots of rose $-55.07 \%$, in a smaller percentage the roots of yew -40.79 , the roots of blueberry $-31.33 \%$, and juniper $-28.72 \%$ (Tab. 5). A large share of the total number of isolates was taken by fungi of the genus Fusarium. 23.40\% of these fungi were isolated from the diseased roots of juniper, a lower percentage from the roots of blueberry $-12.05 \%$ and yew $-11.85 \%$, and the lowest from the roots of rose $-2.90 \%$ (Tab. 5). Next in the order of fungi colonizing the diseased root system of the test shrubs was the genus Trichoderma: $27.71 \%$ in blueberry, $15.78 \%$ in yew, $11.70 \%$ in juniper, up to $11.60 \%$ in rose (Tab. 5). Among the dominant fungi colonizing the diseased root system of both juniper and yew shrubs was the fungus Botrytis cinerea $-10.64 \%$ and $10.53 \%$, respectively (Tab. 5 ). Next in the order of dominant fungi isolated from the root system of the above-mentioned shrubs was Rhizoctonia solani $-15.79 \%$ in yew, $8.51 \%$ in juniper (Tab. 5).

On the basis of the results obtained from the isolation of fungi colonizing the aboveground parts, the base of the shoots, and the roots of the test shrubs, it was found that the most numerous of all the isolates obtained both from the aerial parts and the roots, as well as the base of the shoots of the test shrubs, was A. alternata. Such a high number of isolates of $A$. alternata among the fungi colonizing the tested parts of plants is a major threat to their health. This is consistent with the information in the literature (Abeer et al., 2014), indicating the prevalence of fungi of the genus Alternaria. Goetz and Dugan (2006), pointing out the presence of Alternaria spp. in the rhizosphere of coniferous plants, draw attention to their pathogenicity for such plants. Many authors (Kurzawińska and Duda-Surman, 2008; Ghosh et al., 2009; Nasim et al., 2012; Pegg et al., 2014; Kurzawińska et al., 2015) have indicated that Alternaria spp. can infect the leaves, stems, flowers, fruits, and the roots of ornamental plants.
Table 6. Mean necrotic lesion dimensions in the pathogenicity test

\begin{tabular}{llcc}
\hline \multirow{2}{*}{$\begin{array}{l}\text { Plant } \\
\text { species }\end{array}$} & Combination & \multicolumn{2}{c}{$\begin{array}{c}\text { Mean lesion dimensions } \\
(\mathrm{mm})\end{array}$} \\
\cline { 3 - 4 } & & length & width \\
\hline \multirow{2}{*}{ Juniper } & Alternaria alternata & 6.1 & 3.3 \\
& Control & 0 & 0 \\
\multirow{3}{*}{ Rose } & Alternaria alternata & 2.7 & 2.7 \\
& Control & 0 & 0 \\
\multirow{3}{*}{ Yew } & Alternaria alternata & 3.8 & 2.3 \\
& Control & 0 & 0 \\
\multirow{3}{*}{ Blueberry } & Alternaria alternata & 6.9 & 3.2 \\
& Control & 0 & 0 \\
\hline
\end{tabular}

Analysis of the results of the pathogenicity test showed that the isolates of Alternaria alternata had caused disease symptoms on the shoots of the test plants of the same species from which they had been isolated. The necrotic lesions varied in terms of size (Tab. 6). The smallest were those on the stems of rose, and the largest on the shoots of juniper and blueberry. The tissues around the site of penetration of the pathogen became dark-coloured and died. The isolates of $A$. alternata were characterized by statistically significant pathogenicity for the shoots of the shrubs under study (Fig. 1). Significantly the highest pathogenicity of A. alternata was found on the shoots of highbush blueberry and juniper, and the lowest, but also statistically significant, on rose and yew shoots (Fig. 1).

The necrotic lesions on the shoots of juniper were brown, with a distinct small depression formed at the prick site, filled with the mycelium. They had an elongated shape. The necrotic spots on rose stems were grey-brown, and had a clearly round regular shape. Within the spot, there were visible signs of the dead skin tissue peeling off and a pronounced depression of the prick site. The mycelium of $A$. alternata was visible on the surface of the necrotic lesions, but not very abundant. On yew shoots, the colour of the necrotic spots was dark brown to black. Their edges were broad and indistinct, changing at the rim to a light brown colour. The shape of the spots was elongated. The necrotic lesions of the shoots of highbush blueberry were brown, almost black, elongated, with a clear edge, without a rim. The tissues of the skin within the lesions were cracked. In the control combination of all the species of shrubs there were no visible changes around the prick site on the shoots.

The re-isolation of fungi from the inoculated shoots of the test shrubs carried out after the 


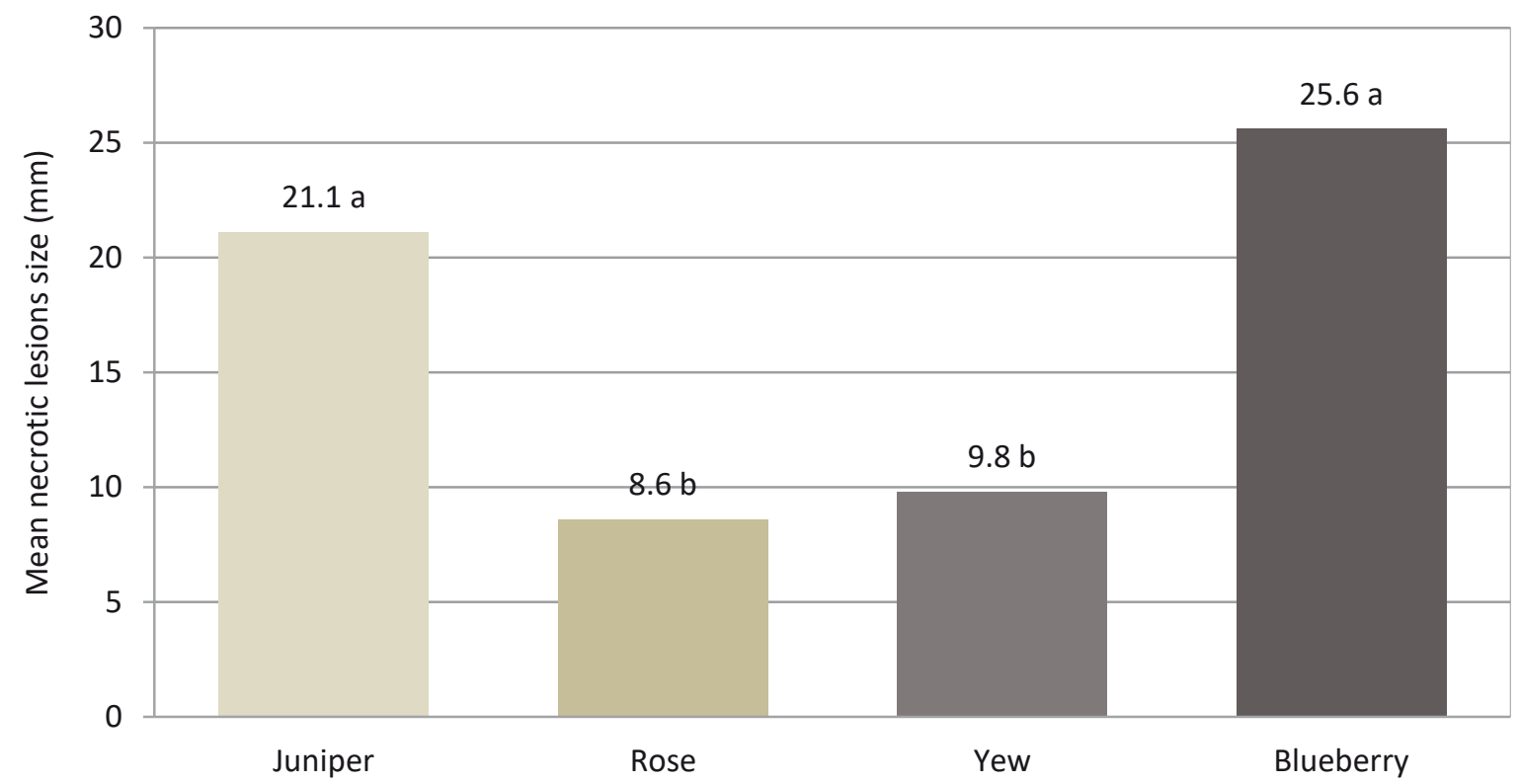

Means followed by the same letter do not differ significantly at $p=0.05$ according to Tukey's multiple range test

Figure 1. Size of necrotic lesions on the tested plant shoots

completion of the experiment confirmed the presence of the tested isolates of A. alternata.

The analysis performed on genomic DNA of the $A$. alternata isolates obtained from the tested species of shrubs showed a similarity between the isolates obtained from juniper and blueberry, and a similarity between the isolates obtained from rose and yew. Comparable results were obtained in both 2011 and 2012. Comparison of the electrophoretic images of RAPD-PCR amplification products of the isolates obtained from juniper and blueberry with the images of the isolates obtained from rose

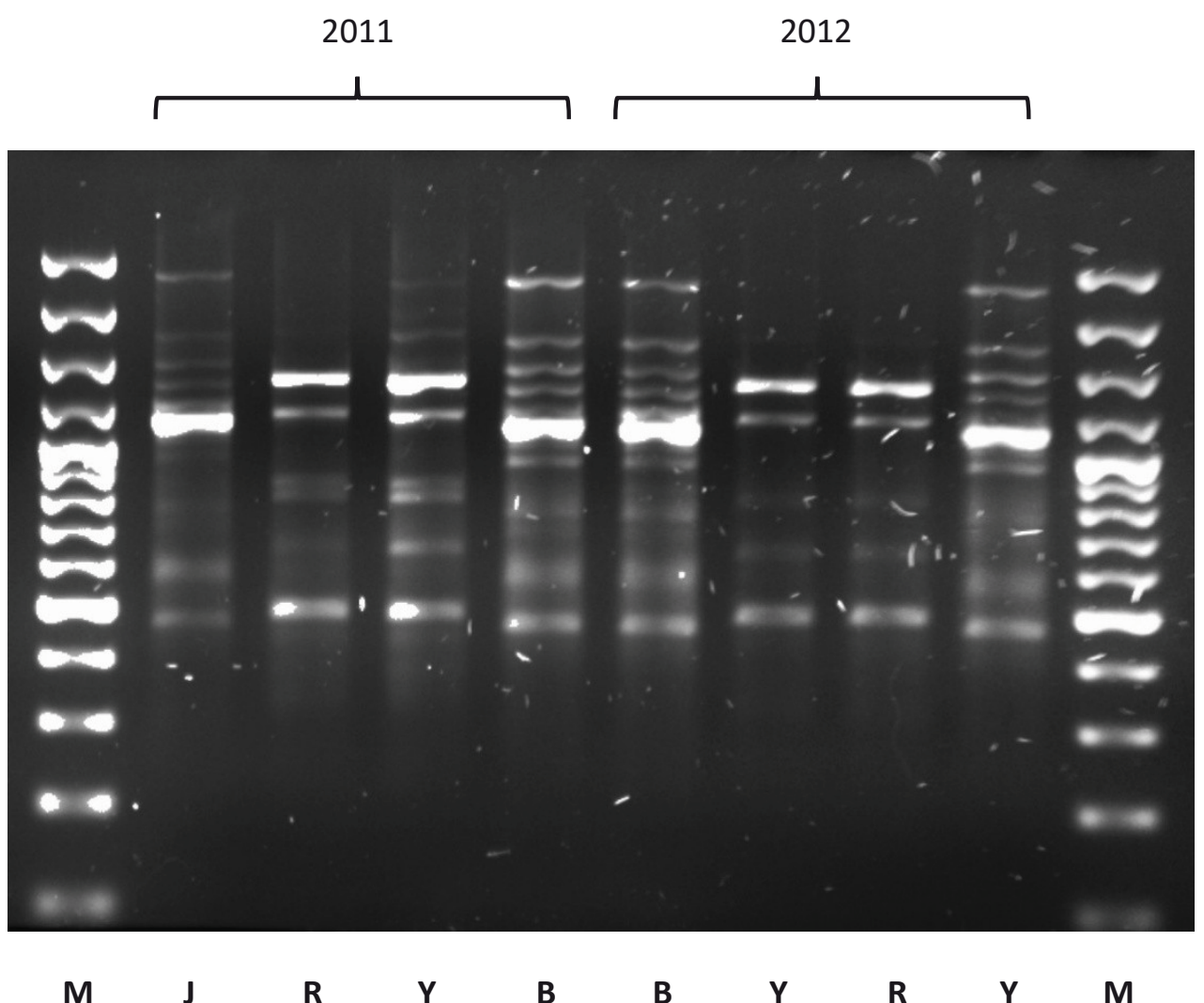

Figure 2. RAPD-PCR amplification products with OPAD12 primer using DNA of Alternaria alternata isolates obtained from the tested shrubs in the years 2011 and 2012 for: $\mathrm{M}$ - marker, J-juniper, R - rose Y - yew, B - blueberry 
and yew provided evidence of genetic variation among $A$. alternata fungi colonizing these shrubs (Fig. 2). Many authors (Tran-Dinh and Hocking, 2006; Sharma et al., 2013; Aneja et al., 2014) have found genetic variation among isolates of A. alternata based on analysis of RAPD bands. Sharma et al. (2013), by analyzing genomic DNA, have also demonstrated genetic variation among isolates of A. alternata obtained from different host plants. PUSZ (2009), on the basis of his results, has indicated that similar pathogenicity is associated with genetic similarity within $A$. alternata populations originating from different host plants and geographic locations. He believes that this finding suggests the ability of A. alternata to easily adapt to closely related host plants.

\section{CONCLUSIONS}

The results of the study are the basis for formulating the following conclusions:

1. The most common disease symptoms in juniper, rose, yew and highbush blueberry were discoloration and withering of the leaves/needles and the shoots of the plants.

2. The diseased leaves/needles, the base of the shoots, and the roots of the tested shrubs were dominated by Alternaria alternata.

3. The A. alternata isolates were pathogenic for the shoots of all the tested species of shrubs.

4. A. alternata can, under favourable conditions, become a facultative pathogen of juniper, rose, yew and highbush blueberry.

\section{FUNDING}

This Research was financed by the Ministry of Science and Higher Education of the Republic of Poland, DS 3500/KOR.

\section{AUTHOR CONTRIBUTIONS}

M.N. and H.K. - designed and performed experiments, analysed data and wrote the paper; M.S. and D.T. - designed and performed experiments, gave suggestions and corrected the manuscript.

\section{CONFLICT OF INTEREST}

Authors declare no conflict of interest.

\section{REFERENCES}

Abeer H., Abd-Allah E.F., Al-Huqail A.A., Alqurawi A.A., 2014. Report and characterization of Alternaria alternata (Fr.) Keissler on Avicennia marina (Forsk.) Vierh forests of industrial Yanb'a city, Saudi Arabia. Pak. J. Bot. 46(2), 725-734.

Agrios G.N., 2005. Plant Pathology. Academic Press, New York, USA.

Andersen B., Nielsen K.F., Pinto V.F., Patriarcha A., 2015. Characterization of Alternaria strains from Argentinean blueberry, tomato, walnut and wheat. Int. J. Food Microbiol. 196, 1-10.

Aneja J.K., Agarwal A., Agnihotri A., 2014. Inter and intra-specific diversity in Alternaria species infecting oilseed Brassicas in India. J. Oilseed Brassica 5(2), 102-117.

Atilano R.A., 1983. Increase of alternaria blight in two ornamental foliage plant species treated by Benomyl, Plant Dis. 67(7), 804-805.

Chase A.R., 2005. Advanced treatment of Alternaria. Pests Dis. 6, 38-44.

Domsch K.H., Gams W., Anderson T.H., 2007. Compendium of Soil Fungi. IHW-Verlag, Eching, Germany.

Dugan F., 2006. The Identification of Fungi: An Illustrated Introduction with Keys, Glossary, and Guide to Literature. APS, St. Paul, USA.

Ellis M.B., Ellis J. P., 1988. Microfungi on Miscellaneous Substrates: An Identification Handbook. Croom Helm, Timber Press, Portland, Oregon, USA.

Ghosh I.P., Mandal D., Laha S., Dasgupta M.K., 2009. Dynamics and severity model in managing fungal diseases. J. Plant Prot. Sci. 1(1), 55-59.

Goetz J., Dugan F.M., 2006. Alternaria malorum: a mini-review with new records for hosts and pathogenicity. Pac. Northwest Fungi 1(3), 1-8.

JAmes R.L., Woo J.Y., 1987. Pathogenicity of Alternaria alternata on young Douglas-fir and Engelman spruce germlings. Report 87-9.

Kakalíková L., Janura E., ŠrobárovÁ A., 2009. First report of Alternaria bunch rot of grapevines in Slovakia. Australas. Plant Dis. Notes 4, 68-69.

Kakvan N., Zamanizadeh H., Morid B., Taheri H., HAJMANSOR S., 2012. Study on pathogenic and genetic diversity of Alternaria alternata isolated from citrus hybrids of Iran, based on RAPD-PCR technique. Eur. J. Exp. Biol. 2(3), 570-576.

Klaus H., Domsch W., Gams W., Anderson T., 2008. Compendium of Soil Fungi. APS, St. Paul, USA.

Kurzawińska H., Duda-Surman J., 2008. In vitro efficiency of bio-preparations against Stewartia pseudocamellia (Max.) pathogens. Sodininkyste ir Darżininkyste 27(2), 427-435.

Kurzawińska H., Mazur S., Nadziakiewicz M., NAWrocki J., 2015. Redroot pigweed as a host for Alternaria alternata - the causal agent of Alternaria leaf blight in potato. Zemdirbyste-Agriculture 102, 115-118.

Kwaśna H., CheŁkowski J., Zajkowski P., 1991. Grzyby (Mycota), tom XXII Sierpik (Fusarium). 
Fungi (Mycota), Volume XXII (Fusarium). Polska Akademia Nauk, Flora Polska, Warszawa.

Larrañaga1 P., Díaz-Dellavalle P., Cabrera1 A., Alem D., Leoni C., Luis A., Souza A., GiovanniDe-Simone S., Dalla-Rizza M., 2012. Activity of naturally derived antimicrobial peptides against filamentous fungi relevant for agriculture. Sustain. Agr. Res. 1(2), 211-221.

Lou J., Fu L., Peng Y., Zhou L., 2013. Metabolites from Alternaria fungi and their bioactivities. Molecules 18, 5891-5935.

Nasim G., Khan S., Khokhar I., 2012. Molecular polimorfizm and phylogenetic relationship of some Alternaria alternata isolates. Pak. J. Bot. 44(4), 12671270.

Pegg K., Duff J., Manners A., 2014. Alternaria diseases in production nurseries. Nursery Production Plant Health \& Biosecurity Project, Australia, 6 pp.

Perello A.E., Sisterna M.N., 2006. Leaf blight of wheat caused by Alternaria triticina in Argentina. Plant Pathol. 55, 303.
Pomerleau R., Nadeau I., 1960. New data on the damping-off of conifer seedlings in Quebec. Report of the Quebec Society for the Protection of Plants from Insects and Fungus Diseases, 27-42.

Pusz W., 2009. Morpho-physiological and molecular analyses of Alternaria alternata isolated from seeds of Amaranthus. Phytopathologia 54, 5-14.

RifFAI M.A., 1969. A revision of the genus Trichoderma. Mycol. Pap. 116, 1-56.

Sharma M., Ghosh R., Pande S., 2013. Occurrence of Alternaria alternata causing Alternaria blight in pigeonpea in India. Adv. Biosci. Biotechnol. 4, 702705.

Tran-Dinh N., Hocking A., 2006. Isolation and characterization of polymorphic microsatellite markers for Alternaria alternata. Mol. Ecol. 6 (2), 405-407.

WindHAm A.S., 2008. Identification and management of plant diseases in landscapes. Extension Soil Plant and Pest Center, Nashville, USA.

Received October 17, 2017; accepted December 5, 2017 